\title{
ANÁLISE DA VIBRAÇÃO DA FERRAMENTA NO PROCESSO DE FRESAMENTO DE LIGA DE TITÂNIO COM AMORTECIMENTO NA
}

\section{FERRAMENTA}

\author{
Lorenzo B. R. Mazzo(IC), Anselmo E. Diniz(PQ)
}

\section{Resumo}

O fresamento de titânio é um processo muito utilizado na indústria porém existem muitos problemas com o processo, o principal deles é a alta taxa de desgaste da ferramenta, fazendo com que o processo seja feito do modo muito lento. O objetivo desse trabalho é reduzir a vibração na ferramenta pela inserção de esferas no porta ferramentas reduzindo assim o desgaste da ferramenta na.

Palavras Chave: Fresamento de titânio, Vibrações, Vida de ferramenta

\section{Introdução}

Ligas de titânio apresentam ótimas características como alta resistência mecânica em relação ao seu peso, mantida a altas temperaturas, e sua resistência a corrosão o que o torna muito utilizável principalmente pela indústria aeroespacial, porém apresentam baixíssima usinabilidade[1]. O objetivo desse trabalho é verificar se a inserção de esferas no porta ferramentas é capaz de diminuir sua vibração levando a uma maior vida de ferramenta

\section{Resultados e Discussão}

Ensaios foram realizados com três tamanhos de esferas diferentes, esferas pequenas médias e grandes. A figura 1 mostra o volume de material total removido até o fim de vida da ferramenta para os diferentes tamanhos de esferas e para o porta ferramentas maciço.

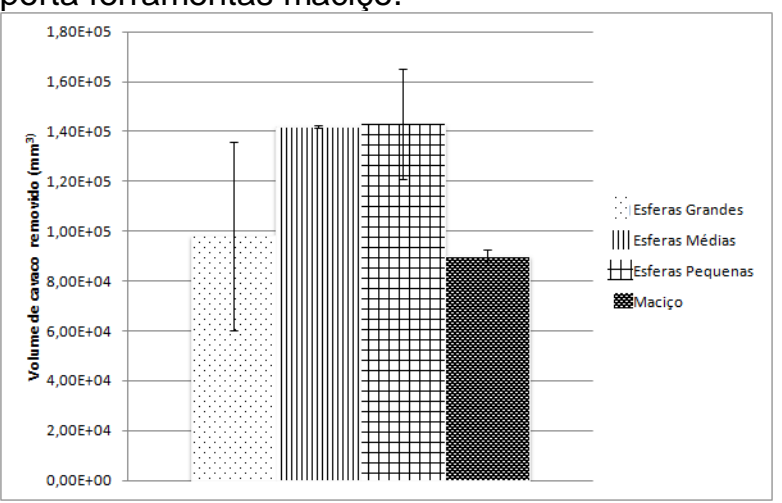

Figura 1. Volume de cavaco removido

É possível se observar na figura que a inserção das esferas médias e pequenas levou a um aumento de aproximadamente $64 \%$ na vida média da ferramenta em relação ao porta ferramentas maciço, enquanto que as esferas grandes quase não interferiram na vida da ferramenta, ainda mais considerando a grande dispersão dos resultados.

Além disso dados obtidos sobre a rugosidade mostram que a inserção de esfera leva a uma melhora em relação ao porta ferramentas furado.

Figura 1: Volume de cavaco removido

\section{Conclusões}

A partir dos dados obtidos pelos ensaios e apresentados aqui, pode-se concluir que as esferas geram um efeito de amortecimento significativo no sistema, aumentando o volume total removido por vida de ferramenta em todos os casos. Além disso, constatou-se que o tamanho e número de esferas realmente interferem na capacidade de amortecimento.

\section{Agradecimentos}

Este trabalho não poderia ser terminado sem a ajuda de diversas pessoas às quais presto minha homenagem:

Prof. Aristides Magri por me auxiliar na execução dos ensaios de fresamento.

Prof. Dr. Anselmo Eduardo Diniz pelo apoio sempre que precisei tirar alguma duvida e pela excelente revisão do trabalho.

1 Ezugwu E O, Wang Z M (1997) Titanium alloys and their machinability - a review. Journal of Materials Processing Technology 68:262-274. 